Journal of Sport Coaching and Physical Education 3 (1)(2018)

\title{
VIDEOTAPES FEEDBACK UNTUK MENINGKATKAN PRESTASI ATLET NOMOR LEMPAR ATLETIK
}

\section{Anggit Wicaksono}

Jurusan Pendidikan Kepelatihan Olahraga, Fakultas Ilmu Keolahragaan, Universitas Negeri Semarang, Indonesia

Info Artikel

Sejarah Artikel:

Diterima Juni 2018

Disetujui Juli 2018

Dipublikasikan

Agustus 2018

Keywords:

Videotape, Feedback, Atletik

\begin{abstract}
Abstrak
Tujuan penelitian ini adalah mengetahui pengaruh videotapes feedback terhadap prestasi atlet nomor lempar atletik UNNES. Penelitian ini menggunakan metode eksperimen dengan one group pretest and posttest design. Sampel penelitian merupakan 7 atlet nomor lempar yang mendapatkan 14 kali perlakuan. Perlakuan yang diberikan adalah pemberian umpan balik menggunakan rekaman video. Data yang dianalisa adalah data lemparan sebelum dan sesudah diberi perlakuan. Analisis data menggunakan uji beda mean berpasangan dengan SPSS. Hasil analisis data diperoleh nilai thitung sebesar -3.401 yang lebih kecil dari nilai t-tabel $-2.447(\mathrm{df}=6)$ yang berarti ada perbedaan yang signifikan antara data tes awal dengan data tes akhir. Apabila dilakukan penelitian dengan adanya kelompok kontrol maka hasil penelitian akan menjadi lebih baik.
\end{abstract}

\begin{abstract}
The purpose of this study was to determine the effect of feedback videotapes on the achievements of athletes in UNNES athletic throwing numbers. This study uses an experimental method with one group pretest and posttest design. The study sample consisted of 7 throwing number athletes who received 14 treatments. The treatment given is giving feedback using video recordings. The data analyzed is throw before and after treatment. Data analysis using mean difference test paired with SPSS. The results of data analysis obtained tcount value of -3.401 which is smaller than the t-table value of $-2.447(d f=6)$ which means there is a significant difference between the initial test data and the final test data. If research is conducted with the control group, the results of the research will be better.
\end{abstract}

\footnotetext{
Alamat korespondensi:

Gedung F1 Lantai 3 FIK UNNES

Kampus Sekaran, Gunungpati, Semarang, 50229

E-mail: jscpe.pklo@unnes.ac.id
} 


\section{PENDAHULUAN}

UNNES memiliki atlet berpotensi pada nomor lempar cabang olahraga atletik. Potensi itu dapat dilihat dari catatan prestasi atlet. Akan tetapi mayoritas atlet belum mencapai prestasi maksimal. Berdasarkan hasil observasi dan wawancara dengan pelatih maupun atlet ditarik sebuah permasalahan yaitu umpan balik yang kurang berkualitas. Selama ini pelatih menggunakan umpan balik secara verbal dengan berbagai kelebihan dan kekurangannya. Dalam penelitian ini peneliti akan memberikan perlakuan umpan balik menggunakan rekaman video.

Feedback atau umpan balik adalah informasi, saran, atau masukan yang diterima pelaku mengenai kinerja pelaku (Christina dan Corcos 1988: 85). Penelitian secara konsisten menemukan bahwa umpan balik menjadi salah satu faktor yang sangat kuat dalam mempengaruhi belajar keterampilan motorik. Dengan demikian, setiap peningkatan kualitas pelatih dalam memberikan umpan balik menentukan seberapa cepat dan baik keterampilan dapat dicapai oleh atlet. Ada beberapa hal yang menjadi poin penting dalam memberikan umpan balik.

Poin yang pertama adalah frekuensi dalam memberikan umpan balik. Ketika pemain mulai mempraktikkan teknik baru, penting bagi pelatih hadir untuk memberikan umpan balik yang cukup konstan. Pemberian umpan balik setelah empat atau lima gerakan cukup untuk memastikan bahwa pemain akan berlatih dengan pemahaman yang baik. Kurangnya umpan balik sering bisa mengakibatkan pemahaman yang tidak lengkap. Di sisi lain, umpan balik yang berlebihan dapat menjadi kontraproduktif. Ketika umpan balik diberikan setelah setiap kali gerakan dapat menjadikan beban bagi atlet (Groppel et al. 1989).

Poin kedua adalah kualitas umpan balik yang merupakan elemen yang sangat penting dari umpan balik. Umpan balik dibagi dalam kategori umum dan khusus berdasarkan kualitasnya. Umpan balik umum adalah umpan balik yang tidak spesifik menunjukan kelebihan atau kekurangan dari kinerja yang dilakukan atlet secara umum. Umpan balik khusus adalah umpan balik yang secara spesifik menunjukkan kesalahan, kekurangan, dan ketepatan dari kinerja yang dilakukan atlet. Maka dapat disimpulkan umpan balik khusus lebih berkualitas dibanding umpan balik umum. Pemberian umpan balik khusus lebih efektif dari umpan balik umum, karena atlet dapat mengetahui kesalahan dan belajar menganalisis gerakan. Kemampuan analisis seorang pelatih merupakan kunci utama dalam menentukan kualitas umpan balik (Groppel et al. 1989).

Umpan balik terbagi menjadi 2 tipe, yaitu : Intrinsic feedback dan augmented feedback (Christina dan Corcos 1988).

Intrinsic feedback

Intrinsic feedback adalah informasi atau umpan balik yang diterima atlet yang berasal dari dalam diri atlet itu sendiri mengenai kinerja yang dilakukan atlet. Otot, tendon, dan sendi-sendi menangkap informasi mengenai gerakan yang dilakukan. Mata menangkap informasi secara visual. Pada intinya semua panca indera manusia digunakan untuk menangkap informasi suatu gerakan yang kemudian digunakan sebagai bahan evaluasi terhadap suatu kinerja (Christina dan Corcos 1988). 
Augmented feedback

Augmented feedback adalah informasi atau umpan balik yang diterima atlet yang berasal dari sumber di luar diri atlet mengenai kinerja yang dilakukan atlet. Sumber augmented feedback dapat berasal dari pelatih, teman satu tim, cermin, rekaman video, dan lain sebagainya (Christina dan Corcos 1988).

Umpan balik baik dengan intrinsic feedback maupun augmented feedback mempunyai fungsi yang sama yaitu sebagai: Informasi

Umpan balik yang berfungsi sebagai informasi untuk mengkoreksi kinerja atlet mengandung isi tentang:

Hasil kinerja atau akibat dari performa atlet (pengetahuan hasil).

Gerakan menghasilkan sensasi yang menyertai performa (kinesthetic feedback).

Mengidentifikasi bagian-bagian dari keterampilan yang dilakukan dengan benar dan tidak benar (pengetahuan tentang kinerja).

Penjelasan mengenai penyebab terjadinya kesalahan.

Perubahan teknik yang harus dilakukan untuk memperbaiki kesalahan.

Menjelaskan alasan mengapa perubahan-perubahan teknik tertentu tersebut direkomendasikan.

Umpan Balik sebagai Penguatan (Reinforcement)

a. Umpan balik yang bertindak sebagai penguat positif memiliki sifat memuji performa atlet sehingga dapat menguatkan kinerja atlet untuk kembali diulang dalam melakukan kinerja yang sama (Christina dan Corcos 1988).

b. Umpan balik yang berfungsi sebagai penguat negatif memiliki sifat yang tidak menyenangkan. Tujuannya adalah untuk menghapus respon atlet yang tidak diinginkan. Sehingga atlet akan berusaha untuk tidak melakukan kesalahan yang sama (Christina dan Corcos 1988).

c. Umpan balik sebagai hukuman berisi umpan balik yang disertai hukuman untuk menghilangkan kesalahan. Seperti umpan balik digunakan sebagai penguat negatif, umpan balik yang berfungsi sebagai hukuman juga memiliki sifat yang tidak menyenangkan. Setiap kali atlet melakukan respon yang tidak diinginkan akan mendapat umpan balik berupa hukuman yang bertujuan untuk menghapus respon tersebut agar tidak diulang pada kinerja maupun kondisi yang sama di masa yang akan datang (Christina dan Corcos 1988).

d. Umpan Balik Sebagai Motivasi

Menurut Robert W. Christina dan Daniel M. Corcos (1988), umpan balik sebagai motivasi memiliki pengaruh kuat bagi atlet, memotivasi atlet untuk belajar keterampilan baru dan memperbaiki atau melakukan yang dipelajari sebelumnya. Motivasi merupakan mekanisme internal yang membangkitkan dan mengarahkan perilaku kita. Proses latihan akan semakin berkualitas apabila atlet yang berlatih mempunyai motivasi tinggi untuk mencapai prestasi maksimal. Motivasi biasanya disampaikan secara lisan yang isinya dapat berupa pujian, kalimat penyemangat, kisah inspirasi, dan berbagai cara lainnya. Dari berbagai cara untuk memotivasi, semuanya memiliki satu tujuan yaitu untuk meningkatkan semangat, kepercayaan diri, dan keyakinan akan kemampuan diri atlet dalam mencapai prestasi puncak yang disertai dengan pelaksanaan latihan dengan displin dan penuh semangat.

Tujuan dari latihan adalah tercapainya sebuah keterampilan gerak. Latihan yang tepat dan terprogram akan menghasilkan keterampilan gerak yang baik. 
Sebaliknya, kurangnya pengetahuan akan bentuk latihan bisa membawa ke arah penguasaan keterampilan yang buruk bahkan menyebabkan cidera. Allan Munro dan Lee Herrington melakukan penelitian dengan memberikan perlakuan berupa metode videotapes feedback untuk mengurangi resiko cidera anterior criciate ligament (ACL) dan sendi patellofemoral. Hasil penelitian tersebut menunjukkan bahwa videotapes feedback berhasil menurunkan vertical ground reaction force dan waktu kontak secara signifikan sehingga mengurangi resiko cidera ACL dan sendi patellofemoral (The Knee, 2014).

Romack dan Valantine melakukan penelitian mengenai videotapes feedback dan memberikan beberapa rekomendasi pada penelitian sejenis antara lain; 1) mentargetkan atlet yang secara spesifik membutuhkan motivasi, 2) menggunakan videotapes feedback secara teratur sebagai alat assessment dan menyimpannya pada alat penyimpanan data personal harian, 3) membandingkan antara video penampilan gerak atlet binaan dengan video penampilan gerak ideal yang dilakukan oleh atlet lain. Videotapes feedback dapat diterapkan untuk mempelajari keterampilan gerak pada cabang olahraga apapun (Journal of Strength and Conditioning, 2005).

\section{METODE PENELITIAN}

Penelitian ini merupakan penelitian kuantitatif menggunakan metode penelitian eksperimen. Model yang digunakan adalah one group pretest posttest design, yaitu eksperimen yang dilaksanakan pada satu kelompok saja tanpa kelompok pembanding. Tes awal dilakukan untuk mengetahui kemampuan awal sampel. Data yang diambil pada saat tes awal adalah jauhnya lemparan. Tahap selanjutnya adalah perlakuan. Perlakuan dilakukan 14 kali dengan memberikan videotapes feedback kepada atlet nomor lempar. Setelah diberikan perlakuan maka tahap berikutnya adalah tes akhir dengan mengambil data jauhnya lemparan.

Sampel pada penelitian ini adalah atlet nomor lempar cabang olahraga atletik UNNES yang berjumlah 7 orang. Atlet tersebut merupakan mahasiswa aktif UNNES yang memiliki potensi untuk meraih prestasi maksimal. Tes awal dan tes akhir menggunakan instrumen tes tolak peluru, instrumen tes lempar cakram, dan istrumen tes lempar lembing yang valid dan reliabel. Alat yang digunakan antara lain peluru, cakram, dan lembing yang sesuai dengan aturan IAAF, serta alat pengukur jarak yang telah ditera.

\section{HASIL DAN PEMBAHASAN}

Tim peneliti telah melakukan tes awal dan 14 kali perlakuan dan tes akhir. Tes awal dilakukan dengan mengambil data lemparan atlet tolak peluru, lempar cakram, dan lempar lembing. Masing-masing sampel melakukan 2 kali lemparan, dan lemparan terjauh yang digunakan sebagai data penelitian.

Tahap berikutnya setelah melakukan tes awal adalah pemberian perlakuan penelitian. Peneliti merekam penampilan gerak sampel pada saat melakukan lemparan. Setelah itu rekaman video tersebut dianalisis menggunakan Dartfish Analysis Motion. Ada beberapa kesalahan yang dilakukan oleh sampel. Dan ini menjadi bahan evaluasi yang sangat penting untuk memperbaiki penampilan gerak sampel. 
Kesalahan gerak pada perlakuan pertama merupakan catatan awal yang menjadi poin-poin umpan balik. Dari perlakuan pertama hingga perlakuan ke empatbelas, dapat dilihat adanya perbaikan penampilan gerak yang dilakukan oleh sampel. Perbaikan penampilan gerak belum bersifat permanen. Beberapa kali sampel menunjukkan penampilan yang sama seperti pada saat perlakuan pertama. Hal tersebut dikarenakan sampel telah menggunakan penampilan gerak tersebut secara bertahuntahun. Sehingga butuh waktu dan proses yang intensif dalam memperbaiki penampilan gerak sampel. Namun demikian, tren penampilan gerak atlet semakin baik dan konsisten pada setiap pertemuan.

Setelah dilakukan perlakuan sebanyak 14 kali pertemuan, kemudian dilakukan tes akhir guna memperoleh data akhir. Tes akhir dilakukan dengan mengambil data lemparan atlet tolak peluru, lempar cakram, dan lempar lembing. Masing-masing sampel melakukan 2 kali lemparan, dan lemparan terjauh yang digunakan sebagai data penelitian.

Data tes awal dan data tes akhir kemudian dianalisis menggunakan uji-T dengan taraf signifikansi 5\%. Tabel berikut menunjukkan hasil analisis data menggunakan program SPSS.

Berdasarkan analisis data tersebut diperoleh nilai t-hitung sebesar -3.401 yang lebih kecil dari nilai t-tabel -2.447 yang berarti ada perbedaan yang signifikan antara data tes awal dengan data tes akhir.

Hasil analisis data menunjukkan ada perbedaan yang signifikan antara data tes awal dengan data tes akhir. Perbedaan yang dimaksud adalah perbedaan yang positif. Terjadi peningkatan prestasi atlet nomor lempar PPLM Atletik UNNES. Hal ini menunjukkan bahwa peningkatan yang terjadi merupakan akibat dari perlakuan yaitu metode videotapes feedback dalam proses latihan.

\section{SIMPULAN}

Kesimpulan dari penelitian ini adalah metode videotapes feedback memberikan pengaruh terhadap hasil lemparan pada nomor lempar cabang olahraga atletik. Pengaruh tersebut bersifat positif yang artinya dengan menggunakan metode videotapes feedback dapat meningkatkan penampilan gerak atlet yang berimplikasi pada jauhnya lemparan.

Saran bagi pelatih untuk menggunakan metode videotapes feedback dalam membina atletnya. Metode videotapes feedback tidak harus menggunakan peralatan khusus analisa gerak yang mahal dan terbatas. Pelatih dapat memanfaatkan alat perekam video sederhana seperti yang tersedia di telepon genggam. Yang ditekankan lebih kepada detail umpan balik yang diberikan berdasarkan hasil rekaman video.

Selain pelatih, atletpun dapat turut merekam penampilan geraknya sendiri untuk melihat penampilan gerak yang dilakukannya sehingga dapat mengetahui secara pasti kesalahan gerak yang dilakukan. Untuk memperbaikinya selain umpan balik dari pelatih, atlet juga dapat membandingkan video rekaman penampilan geraknya dengan video rekaman atlet dunia yang penampilannya efektif dan efisien sehingga bisa dijadikan pembanding dan rujukan.

Bagi peneliti lain dihimbau untuk menambah jumlah sampel, mengkhususkan pada salah satu nomor lempar, dan 
mengantisipasi kendala-kendala non teknis yang bisa saja muncul. Penelitian tidak terbatas pada cabang olahraga atletik nomor lempar, tetapi juga dapat dilakukan pada nomor atletik yang lain dan pada berbagai cabang olahraga.

\section{DAFTAR PUSTAKA}

Christina, R.W. dan D.M. Corcos. 1988. Coaches Guide to Teaching Sport Skills. Illinois: Human Kinetics.

Groppel, J.L. et al. 1989. Science of Coaching Tennis. USA: Leisure Press.

Munro, A. dan Herrington, L. 2014. The Knee, 21 (5), 891-895. Amsterdam: Elsevier.

Romack, J.L. dan Valantine, A.D. 2005. Journal of Strength and Conditioning, 27 (3), 60-63. USA: Wolters Kluwer Health, Inc. 